This rapid communication was first published in the October 1999 issue of Journal of Endocrinology 163 R1-R4. Regrettably, the names of the first two authors were printed incorrectly, so the entire article is reprinted here. The journal apologizes for this error and any confusion it has caused.

\title{
Abundance of leptin mRNA in fetal adipose tissue is related to fetal body weight
}

\author{
B S J Yuen ${ }^{1}$, I C McMillen ${ }^{1}$, M E Symonds ${ }^{3}$ and P C Owens ${ }^{2}$
}

${ }^{1}$ Department of Physiology, University of Adelaide, Adelaide 5005, Australia

2Department of Obstetrics and Gynaecology, University of Adelaide, Adelaide 5005, Australia

${ }^{3}$ Academic Division of Child Health, School of Human Development, Queen's Medical Centre, Nottingham, UK

\begin{abstract}
Leptin mRNA was measured in adipose tissue of fetal sheep by reverse transcription polymerase chain reaction (RTPCR). Abundance of leptin mRNA relative to $\beta$-actin mRNA in fetal perirenal adipose tissue increased $(P<0.02)$ with gestation, being higher at $144 \mathrm{~d}(0.73 \pm 0.10, n=5)$ than at $90-91 \mathrm{~d}(0.40 \pm$ $0.08, n=6)$ or $125 \mathrm{~d}(0.40 \pm 0.04, n=5)$ gestation (term $\sim 147$ $150 \mathrm{~d})$. There was a positive relationship between relative abundance of leptin mRNA $(y)$ and fetal body weight $(x)$ between 90 and $144 \mathrm{~d}$ gestation $\left(\mathrm{r}^{2}=0.27, P<0.01\right)$. The slope
\end{abstract}

\section{Introduction}

Leptin is a $16 \mathrm{kDa}$ polypeptide hormone synthesised and secreted by adipocytes that acts to suppress appetite and increase energy expenditure in adults (Friedman \& Halaas 1998, Houseknecht et al. 1998). Abundance of leptin mRNA in adipose tissue and concentrations of leptin protein in blood correlate positively with body weight and adiposity in human adults (Maffei et al. 1995, Considine et al. 1996). In rodents leptin mRNA is expressed in a number of fetal tissues including cartilage, hair follicles and placenta (Senaris et al. 1997, Hoggard et al. 1997, Masuzaki et al. 1997) and in humans there is a positive association between leptin levels in cord blood and body weight at birth (Schubring et al. 1997, Koistinen et al. 1997, Ong et al. 1999). These data suggest there is a relationship between growth and leptin synthesis before birth, but there have been no reports relating fetal expression of leptin to fetal growth. We have measured leptin mRNA in perirenal fat, the major adipose tissue in the sheep fetus. We also investigated the relationship between leptin mRNA and fetal weight before (90-91 d) and after (125-144 d gestation) the development of sympathetic innervation of the perirenal fat depot (Gemmell \& Alexander 1978, Clarke et al. 1997).

\section{Materials and Methods}

Animals

The study design was approved by the Animal Ethics Committee of the University of Adelaide. Merino ewes $(n=51)$ of the linear dependence of leptin mRNA on fetal weight was 15 -fold greater $(P<0.001)$ at $90-91 \mathrm{~d}(y=2.81 x-1.1, n=6$, $\left.\mathrm{r}^{2}=0.71, P<0.025\right)$ than between $125-144 \mathrm{~d}$ gestation $(y=$ $\left.0.195 x-0.15, n=16, \mathrm{r}^{2}=0.39, P<0.01\right)$. Thus the leptin synthetic capacity of fetal adipose tissue appears to increase in late gestation but this is accompanied by constraint of its sensitivity to fetal body weight. We hypothesise that leptin synthesis in fetal adipose tissue is related to fetal nutrient supply and growth rate.

Journal of Endocrinology (1999) 163, R11-R14

were mated and provided unrestricted access to feed and water. They were killed between 90 and $145 \mathrm{~d}$ of pregnancy (term $\sim 147-150 \mathrm{~d}$ ) with an overdose of sodium pentobarbitone (6.5 g i.v.) and the fetuses were removed and weighed. In one group ( $n=29,12$ male and 17 female) of singletons $(n=12)$ and twins ( $n=17$ fetuses from 12 ewes), both left and right fetal perirenal fat depots were collected between 90-99 d $(n=9)$ and 137-145 d $(n=20)$ and weighed. In another group consisting entirely of twins a biopsy of fetal perirenal adipose tissue was obtained from one twin at 90-91 d (n=6), $125 \mathrm{~d}(n=5), 139-141$ $\mathrm{d}(n=6)$ and $144 \mathrm{~d}(n=5)$, quickly frozen in liquid $\mathrm{N}_{2}$ and stored at $-80{ }^{\circ} \mathrm{C}$ for measurement of leptin and $\beta$-actin mRNA.

\section{Reverse transcription polymerase chain reactions}

RNA was extracted from $\sim 100 \mathrm{mg}$ adipose tissue (Tri Reagent, Prod T9424, Sigma) as recommended. cDNA was obtained by reverse transcription of $2 \mu \mathrm{g}$ total RNA with random sequence hexanucleotides (Cat RP-6, GeneWorks, Adelaide, Australia) using Super-Script RNase H- (Cat 18053-017, GIBCOBRL). A fragment of ovine leptin cDNA was amplified through 26 cycles of $60 \mathrm{sec}$ at $94{ }^{\circ} \mathrm{C}, 15 \mathrm{sec}$ at $53{ }^{\circ} \mathrm{C}$ and $60 \mathrm{sec}$ at $72{ }^{\circ} \mathrm{C}$ (Hybaid PCR Express, Teddington, UK) from $5 \mu$ of reverse transcription product using Taq* DNA polymerase (Biotech International, Bently, Australia) as recommended by the manufacturer with 5'-GACATCTCACACACGCAG-3' and 5'GAGGTTCTCCAGGTCATT-3' (GeneWorks) as primers. This produced $183 \mathrm{bp}$ of ovine leptin ds cDNA (nucleotides 67-249 of the 441 nucleotide cDNA of ovine leptin, Genbank 


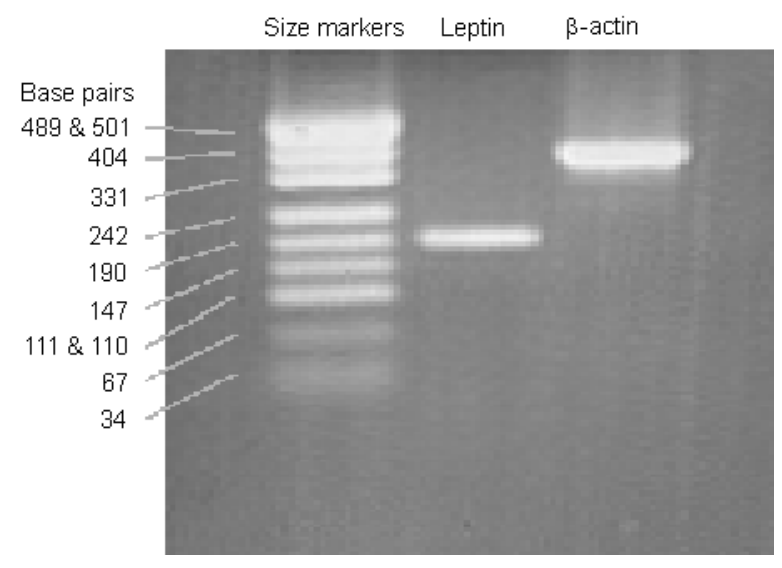

Figure 1 Agarose electrophoresis of RTPCR products.

Acc. No. U 84247). Sequencing with the ABI PRISM Dye Terminator method (Perkin-Elmer Corp) after QIA-quick purification (QIAGEN Pty. Ltd., Clifton Hill VIC, Australia) confirmed its identity. A 349 bp fragment of ovine $\beta$-actin cDNA was similarly amplified with 5'TGTGATGGTGGGTATATGGGTC-3' and 5'-TAGATGGGCACAGTGTGGGT-3' and its identity was confirmed by homology with rat $\beta$-actin, GenBank Acc. No. V01217 J00691. Products of RTPCR $(8 \mu \mathrm{l})$ were electrophoresed through a $1.5 \%(\mathrm{w} / \mathrm{v})$ agarose gel. This was stained with ethidium bromide, transilluminated with UV light and photographed. Intensities of RTPCR products were measured on the film negative by laser densitometry. Molecular sizes of PCR products were estimated by comparing their electrophoretic migration with those of fragments of pUC19 ds DNA digested with Hpa II (GeneWorks). Each leptin RTPCR product had a mobility similar to that of the $190 \mathrm{bp}$ fragment of pUC19, consistent with the predicted size of $183 \mathrm{bp}$. The

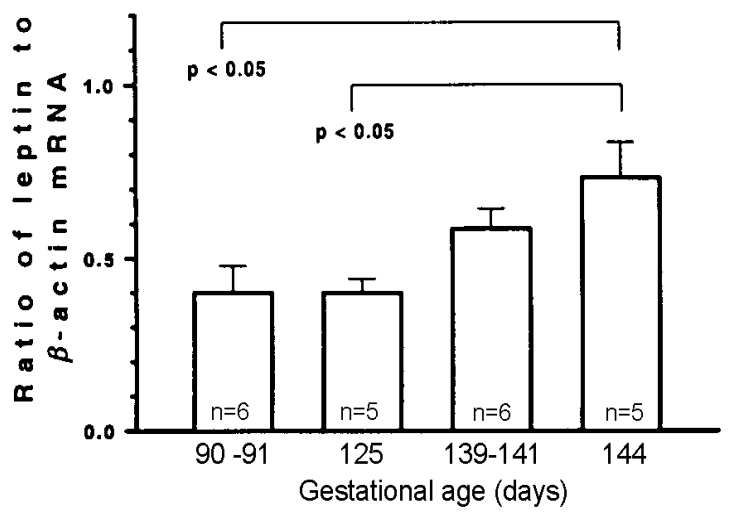

Figure 2 Ontogeny of leptin expression in fetal adipose tissue. mobility of the $\beta$-actin cDNA fragment was intermediate between that of the 331 and 404 bp markers (Fig.1).

\section{Statistics}

Results are presented as mean \pm S.E.M. $(n=$ number of animals). Total perirenal fat mass is the combined weights of the two perirenal fat depots for each fetus. Relative fat mass is the ratio of total perirenal fat mass to body weight of the fetus. Differences between groups were assessed by one- or two-way analysis of variance with Bonferroni's multiple comparison. Associations were evaluated by linear regression (SigmaStat V1, Jandel Scientific). Differences between the slopes of linear regressions were assessed by Student's $t$ test (Zar 1974).

\section{Results}

In the first group studied, which included singletons and twins, gender of fetus had no significant effect on fetal weight, perirenal fat weight or relative fat mass. As expected, fetal weight was affected by number of fetuses per pregnancy $(P<0.01)$, gestational age $(P<0.001)$ and the interaction between these factors $(P<0.05)$. Twin fetuses had lower body weights than singletons and this difference was greater after $137 \mathrm{~d}$ than before $99 \mathrm{~d}$ gestation. Total perirenal fat weight $(P<0.001)$, but not relative fat mass, increased with gestation and was unaffected by the number of fetuses per pregnancy.

In the second group, which consisted entirely of twins of which one of each pair was examined, relative abundance of leptin mRNA in fetal perirenal adipose tissue increased $(P<0.02)$ with gestation (Fig. 2). Abundance of leptin mRNA relative to $\beta$-actin mRNA $(y)$ in fetal adipose tissue was positively correlated with the weight $(x)$ of the fetus $(y=0.08 x$ $+0.31, n=22, P<0.01)$ such that $27 \%$ of the variance in leptin mRNA could be explained by dependence on fetal weight $\left(\mathrm{r}^{2}=0.27\right)$. The slope of this relationship (Fig. 3) was steeper $(P<0.001)$ at $90-91 \mathrm{~d}\left(y=2.81 x-1.1, n=6, \mathrm{r}^{2}=0.71, P<0.025\right)$ than at $125-144 \mathrm{~d}\left(y=0.195 x-0.15, n=16, \mathrm{r}^{2}=0.39, P<0.01\right)$.

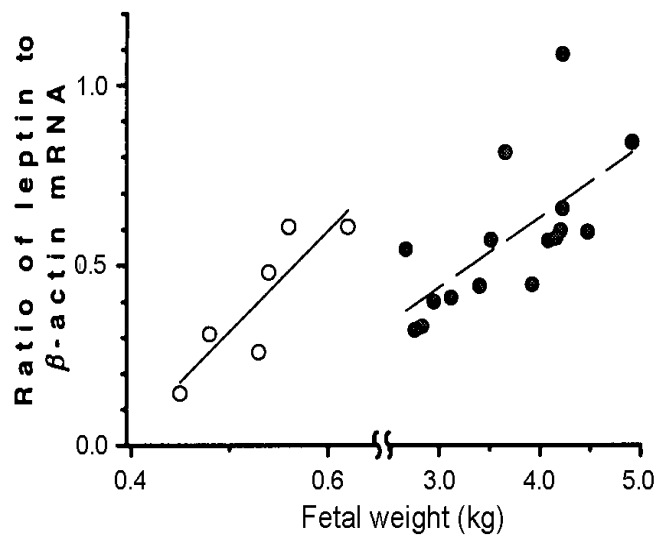

Figure 3 Relationship between leptin mRNA and fetal weight at 90-91 (O) and 125-144 (•) d gestation. 


\section{Discussion}

We have demonstrated for the first time that leptin mRNA is expressed in fetal adipose tissue. Lipid accumulation in the perirenal area of fetal sheep occurs from $\sim 70 \mathrm{~d}$ gestation and there is a marked increase in mitochondria within this tissue between 80 and 90 d (Alexander 1978). After this age, fetal perirenal fat in the sheep consists of brown adipocytes characterised by many mitochondria with numerous cristae (Gemmell \& Alexander 1978). In the rat, leptin is expressed in brown adipose tissue during the first $24 \mathrm{~h}$ after birth (Dessolin et al. 1997). The present study shows that leptin mRNA is expressed in brown adipose tissue before birth.

We found an increase in relative abundance of leptin mRNA in fetal adipose tissue in the last $20 \mathrm{~d}$ before delivery in sheep. This may be due to an increase in size of adipocytes in fetal perirenal fat depots, since there is strong evidence that adipocyte cell size is a major determinant of expression and secretion of leptin (Lonnqvist et al. 1997) and the mean cell volume of perirenal adipocytes in fetal sheep increases 3- to 4fold between 90 and 144 d gestation (Vernon et al. 1981). Alternatively, increased leptin expression in fetal perirenal fat in sheep during late gestation may be related to the rise in circulating fetal cortisol concentrations in the two weeks before delivery (Bassett \& Thorburn 1969). Glucocorticoids stimulate leptin gene expression in adipocytes in vivo (De Vos et al. 1995) and in vitro (Slieker et al. 1996). We observed a positive relationship between abundance of leptin mRNA in fetal adipose tissue and fetal body weight as early as $90 \mathrm{~d}$ gestation (term is $147-150 \mathrm{~d}$ ). This relationship may also be a consequence of greater leptin synthesis occurring in larger adipocytes in bigger fetal sheep. Greater leptin expression in larger fetuses might also be a response to stimulation by anabolic hormones such as insulin. Insulin promotes fetal growth in sheep (Fowden 1995) and stimulates leptin synthesis and secretion in vitro and in vivo postnatally in rats and humans (Gettys et al. 1996, Russell et al. 1998).

Despite greater abundance of leptin mRNA in fetal adipose tissue after $125 \mathrm{~d}$ gestation, the nature of its relationship with body weight changes. The slope of the regression between relative abundance of leptin mRNA and body weight in fetuses of $125 \mathrm{~d}$ gestation and older was 15-times lower than at 90-91 d. Thus although leptin synthetic capacity of fetal adipose tissue appears to increase in late gestation, it is less sensitive to variation in fetal body size than at 90-91 d. This implies that an inhibitory influence appears in late gestation that alters the relationship between leptin expression and fetal size. The lower slope for the relationship between leptin mRNA and fetal weight from $125 \mathrm{~d}$ gestation may be associated with the onset of sympathetic innervation of fetal perirenal adipose tissue, which occurs at $\sim 120 \mathrm{~d}$ gestation in sheep (Gemmell \& Alexander 1978, Clarke et al. 1997). In bovine fetal adipose tissue the abundance of $\beta_{3}$-adrenergic receptors and uncoupling protein-1 increase in late gestation (Casteilla et al. 1987, 1994). Studies in rats and mice have shown that $\beta_{3}$-adrenergic agonists suppress leptin gene expression whilst stimulating expression of uncoupling protein-1 (Fowden 1995, Li et al. 1997, Trayhurn et al. 1996). Regardless of the mechanism(s) responsible for the change in leptin expression with gestation, the relationship between leptin mRNA abundance and fetal size is consistent with the hypothesis that leptin synthesis in fetal adipose tissue is related to fetal nutrient supply and fetal growth rate.

\section{References}

Alexander G 1978 Quantitative development of adipose tissue in foetal sheep. Australian Journal of Biological Science 31 489-503.

Bassett JM \&Thorburn GD 1969 Foetal plasma corticosteroids and the initiation of parturition in sheep. Journal of Endocrinology 44 285-286.

Casteilla L, Forest C, Robelin J, Ricquier-D, Lombet A \& Ailhaud G 1987 Characterisation of mitochondrial-uncoupling protein in bovine fetus and newborn calf. American Journal of Physiology 252 E627-E636.

Casteilla L, Muzzin P, Revelli JP, Ricquier D \& Giacobino JP 1994 Expression of $\beta_{1}$ - and $\beta_{3}$-adrenergic receptor messages and adenylate cyclase $\beta$-adrenergic response of bovine perirenal adipose tissue during its transformation from brown into white fat. Biochemical Journal 297 93-97.

Clarke L, Bryant MJ, Lomax MA \& Symonds ME 1997 Maternal manipulation of brown adipose tissue and liver development in ovine fetus during late gestation. British Journal of Nutrition 77 871-883

Considine RV, Sinha MK, Heiman ML, Kriauciunas A, Thomas W, Stephens TW, Nyce MR, Ohannesian JP, Marco CC, McKee LJ, Bauer TL \& Caro JF 1996 Serum immunoreactive leptin concentrations in normal-weight and obese humans. New England Journal of Medicine 334 292-295.

De Vos P, Saladin R, Auwerx J \& Staels B 1995 Induction of $o b$ gene expression by corticosteroids is accompanied by body weight loss and reduced food intake. Journal of Biological Chemistry $\mathbf{2 7 0}$ 15958-15961.

Dessolin S, Schalling M, Champigny O, Lonnqvist F, Ailhaud G, Dani C \& Ricquier D 1997 Leptin gene is expressed in brown adipose tissue at birth. FASEB Journal 11 382-387.

Fowden AL 1995 Endocrine regulation of fetal growth. Reproduction, Fertility and Development 7 351-363.

Friedman JM \& Halaas JL 1998 Leptin and the regulation of body weight in mammals. Nature 395 763-770.

Gemmell R \& Alexander G 1978 Ultrastructural development of adipose tissue in foetal sheep. Australian Journal of Biological Science 31 505-515.

Gettys TW, Harkness PJ \& Watson PM 1996 The $\beta_{3}$-adrenergic receptor inhibits insulin-stimulated leptin secretion from isolated rat adipocytes. Endocrinology 137 4054-4057.

Hoggard N, Hunter L, Duncan JS, Williams LM, Trayhurn P \& Mercer JG 1997 Leptin and leptin receptor mRNA and protein expression in the murine fetus and placenta. Proceedings of the National Academy of Sciences of the USA 94 11073-11078.

Houseknecht KL, Baile CA, Matteri RL \& Spurlock ME 1998 The biology of leptin: a review. Journal of Animal Science 76 14051420 . 
Koistinen HA, Koivisto VA, Andersson S, Karonen S-L, Kontula K, Oksanen L \& Teramo KA 1997 Leptin concentration in cord blood correlates with intrauterine growth. Journal of Clinical Endocrinology and Metabolsim 82 3328-3330.

Li H, Matheny M \& Scarpace PJ $1997 \beta_{3}$-adrenergic-mediated suppression of leptin gene expression in rats. American Journal of Physiology 272 E1031-E1036.

Lonnqvist F, Nordfors L, Jannson M, Thorne A, Schalling M \& Arner P 1997 Leptin secretion from adipose tissue in women: relationship to plasma levels and gene expression. Journal of Clinical Investigation 99 2398-2404.

Maffei M, Halaas J, Ravussin E, Pratley RE, Lee GH, Zhang Y, Fei H, Kim S, Lallone R, Ranganathan S, Kern PA \& Friedman JM 1995 Leptin levels in human and rodent: measurement of plasma leptin and ob RNA in obese and weight-reduced subjects. Nature Medicine 1 1151-1161.

Masuzaki H, Ogawa Y, Sagawa N, Hosoda K, Matsumoto T, Mise H, Nishimura H, Yoshimasa Y, Tanaka I, Mori T \& Nakao K 1997 Nonadipose tissue production of leptin: leptin as a novel placentaderived hormone in humans. Nature Medicine 3 1029-1033.

Ong KKL, Ahmed ML, Sherriff A, Woods KA, Watts A, Golding J \& Dunger DB 1999 Cord blood leptin is associated with size at birth and predicts infancy weight gain in humans. Journal of Clinical Endocrinology and Metabolism 84 1145-1148.

Russell CD, Petersen RN, Rao SP, Ricci MR, Prasad A, Zhang Y, Brolin RE \& Fried SK 1998 Leptin expression in adipose tissue from obese humans: depot-specific regulation by insulin and dexamethasone. American Journal of Physiology 275 E507-E515.

Senaris R, Garciacaballero T, Casabiell X, Gallego R, Castro R, Considine RV, Dieguez C \& Casanueva FF 1997 Synthesis of leptin in human placenta. Endocrinology 138 4501-4504.

Schubring C, Kiess W, Englaro P, Rascher W, Dotsch J, Hanitsch S, Attanasio A \& Blum WF 1997 Levels of leptin in maternal serum, amniotic fluid and arterial and venous cord blood: relation to neonatal and placental weight. Journal of Clinical Endocrinology and Metabolism 82 1480-1483.

Slieker LJ, Sloop KW, Surface PL, Kriauciunas A, Laquier F, Manetta J, Buevalleskey J \& Stephens TW 1996 Regulation of expression of ob mRNA and protein by glucocorticoids and cAMP. Journal of Biological Chemistry 271 5301-5304.

Trayhurn P, Duncan JS, Rayner DV \& Hardie LJ 1996 Rapid inhibition of $o b$-gene expression and circulating leptin levels in lean mice by $\beta_{3}$-adreno-receptor agonists BRL 35135A and ZD2079.

Biochemical and Biophysical Research Communications 228 605610.

Vernon RG, Clegg RA \& Flint DJ 1981 Aspects of adipose tissue metabolism in foetal lambs. Biochemical Journal 196 819-824.

Zar JH 1974 Comparing simple linear regression equations, 17.1 Comparing Two Slopes. In Biostatistical Analysis, pp 228-229, Prentice-Hall. 